\author{
NBER WORKING PAPER SERIES \\ ON \\ HISTORICAL FACTORS IN LONG RUN GROWTH
}

\title{
THE MEANING OF MONEY IN THE GREAT DEPRESSION
}

\author{
Hugh Rockoff
}

Historical Paper No. 52

\section{NATIONAL BUREAU OF ECONOMIC RESEARCH 1050 Massachusetts Avenue Cambridge, MA 02138 \\ December, 1993}

\begin{abstract}
I must thank Andres Liivak for able research assistance and the Rutgers University Research Council for financial support. The comments received at a seminar at Lehigh University and at the Columbia seminar in economic history were extremely valuable. The remaining errors are mine. This paper is part of NBER's research program in the Historical Development of the American Economy. Any opinions expressed are those of the author and not those of the National Bureau of Economic Research.
\end{abstract}


NBER Historical Paper \#52

December 1993

\title{
THE MEANING OF MONEY IN THE GREAT DEPRESSION
}

\begin{abstract}
The quality of the money stock declined during the banking crises of the early 1930 s. Bank deposits did not serve as a secure short-term store of purchasing power for use in an emergency as well as they had previously, and during the periods of restricted deposits in late 1932 and early 1933, bank deposits could not fulfill their basic function of being a medium of exchange. This paper presents some evidence to show that the decline in the quality of the money stock contributed to the severity of the contraction.
\end{abstract}

Hugh Rockoff

Department of Economics

Rutgers University

New Brunswick, N.J. 08903

and NBER 


\section{Introduction}

This paper argues that a neglected cause of the Great Depression was the decline in the quality of the stock of money. ${ }^{1}$ In other words, it argues that part of the decline in velocity from 1931 to 1933 is a measurement error: the quality-constant stock of money declined more rapidly than the measured stock, and the velocity of the quality-constant stock less rapidly. The idea that the quality of the stock of money declined is in some ways so obvious that someone unfamiliar with the debate over the causes of the Depression will wonder why it needs to be pointed out. Comparisons with standard accounts of the Depression, however, show that the quality-of-money factor has been neglected and, I believe, that as a result too much has been made of nonmonetary factors such as the availability of credit, and possible technological or trade shocks.

In principle the effect of an erosion in quality could be either a reduction in spending or an increase. The direction of the effect depends on the availability of substitutes for bank deposits, the time for adjustment, and so on. This is familiar. In the short-run a decline in the quality of gasoline (fewer miles-per-gallon) might lead people to spend more on gasoline, but in the long run, when more adjustments are possible (purchasing more fuel efficient automobiles, moving close to public transportation, and so on), less might be spent on gasoline. Something similar is true with money. In the short run a decline in the quality of deposits might lead people to accumulate more cash, gold, or other safe assets. In the long run, however, they might find ways to economize on their holdings of liquid assets.

${ }^{1}$ I must thank Andres Liivak for able research assistance and the Rutgers University Research Council for financial support. The comments received at a seminar at Lehigh University and at the Columbia seminar in economic history were extremely valuable. The remaining errors are mine. 
A related distinction is between a once-and-for-all change in quality and a continuous change. A change in quality that was assumed to be over and done would lead people to try to rebuild their liquidity. But the same change in quality might operate in the opposite direction if it was taken as part of an ongoing movement to lower and lower quality. Which type of change characterized the Depression is an empirical issue. Did people imagine themselves, after each banking crisis, on a lower floor (however shaky) or on an escalator moving steadily downward? The argument sketched below assumes that in each phase of the banking crisis consumers behaved as if they could restore their previous levels of liquidity by accumulating monetary assets that appeared to be safe. In retrospect this behavior may have been a mistake, but ex-ante these beliefs may have been rational.

The argument is developed in the following way. Section 1 describes Henry Simons's theory of the Depression, the inspiration for my interpretation. Section 2 describes the nature of the decline in the quality of deposits, and how economic activity was affected. Section 3 contains my preferred procedure for estimating the empirical magnitude of the quality effect. It examines the growth of restricted deposits before the federal bank holiday, proposes a conjectural adjustment to the stock of moeny to account for restricted deposits, and tests the adjusted money stock in equations designed to explain the Depression. Section 4 reports the result of an alternative approach to estimating the effects of quality deterioration. It examines the shift into safe alternatives to deposits and uses these shifts as proxies for quality deterioration. Section 5 briefly assesses the consistency of a quality-decline interpretation of the Great Depression with the experience in other banking crises. Section 6 compares and contrasts the quality-decline interpretation with several well known accounts of the Depression. Section 
7 is a brief conclusion. The appendix explores the divisia index and related indexes of the money supply.

\section{Henry Simons's Theory of the Great Depression}

The argument made here is not a new one: it is an updated version Henry Simons's theory of the Depression. Simons must be counted as one of the leading monetary economists of the century. In particular, his famous essay on "Rules vs. Authorities" set in motion a long train of research that continues to play a major role in monetary economics. The Depression dominated Simons's view of how money worked and how the monetary system should be reformed.

But despite his influence on monetary economics, his view of the causes of the Depression receives almost no attention today.

Simons accepted the quantity theory of money. But he laid great stress on what he called near moneys or practical moneys. His version of the quantity theory, I believe, could be written as follows. ${ }^{2}$

(1) $(C+B 1 T B+B 2 D+B 3 T D+B 4 C P+\ldots) * V=P y$

where $\mathrm{C}$ is currency

TB is treasury bills

$\mathrm{D}$ is deposits

TD is time deposits

${ }^{2}$ I provide a more detailed defense of this interpretation of Simons, and a sketch of the relationship of it to his policy proposals in Rockoff (1993). 
$\mathrm{CP}$ is commercial paper

and the B's are coefficients representing the moneyness of assets (a number between 0 and 1 with $B=1$ for cash).

I have listed here assets that Simons referred to explicitly in his writings (Simons 1948, 326), but he might well have included other assets in his definition, hence the ellipsis at the end of the parentheses.

The Depression, according to Simons, was caused by the banking crises and the associated collapse in the quantity of money substitutes and near moneys and the collapse in the "degree of their general acceptability," the betas in equation 1 (Simons 1948, 164). The decline in conventionally measured stocks, such as M1 or M2, was, in Simons's view, only part of the decline in liquidity that caused the Depression.

Simons's policy proposals, by the way, followed directly from this interpretation. Yet few economists of similar persuasion pondering equation (1) would have been able, I suspect, to make the leap that Simons made. He proposed reforms that would lead to a "financial good society" by eliminating all of the terms in equation (1) that had caused trouble in the 1930s. His proposed changes were as follows. (1) Eliminate TB. All debt issued by the government would be in the form of cash or consols. (2) Eliminate CP and all similar forms of near money by permitting only equity financing of private enterprises. (3) Then set $B 2$ and $B 3=1$, and hold the sum of $\mathrm{C}$ and $\mathrm{D}$ constant through 100 percent bank reserves. In effect these reforms would reduce the quantity equation from (1) to (2) $\mathrm{HV}=\mathrm{Py}$

where $\mathrm{H}$ is highpowered money, cash issued by the government.

The interpretation of Simons offered here differs somewhat from one interpretation that 
has a strong claim to be authoritative. Don Patinkin (1972) depicts Simons as essentially a "classical" quantity theorist in the Irving Fisher tradition and makes no mention of an expanded, quality-adjusted definition of money. Possibly, Simons was concentrated on conveying the received doctrine in the lectures from which Patinkin quotes because they were given in an introductory course. ${ }^{3}$ My interpretation also differs, although in a smaller degree, from the interpretation offered by Milton Friedman in his famous paper "the Monetary Theory and Policy of Henry Simons" (Friedman, 1969). Friedman's point was that Simons had given too much attention to the decline in the Beta's in equation (1) and not enough to the decline in conventionally measured monetary aggregates and the associated decline in $\mathrm{V}$. The empirical work below would seem to be consistent with ranking the decline in the measured stock ahead of the decline in quality. Friedman also emphasized that Simons had underestimated the perverse behavior of the Federal Reserve.

In support of my interpretation, however, I can cite Roland McKean, who was a student of Simons. According to McKean [1951, p. 66] "... in elaborating the quantity theory of money, economists tended to obscure the other balance-sheet items and to focus attention on the influence of one particular asset -- money -- which had to be defined arbitrarily. Some -- Henry Thornton was one of the earliest, and Henry Simons one of the most persuasive -- sought further

\footnotetext{
${ }^{3}$ It is small jump from Fisher's equation to equation (1). Fisher wrote the quantity theory as (1) $\mathrm{MV}+\mathrm{M}^{\prime} \mathrm{V}^{\prime}=\mathrm{PT}$ Divide through by $\mathrm{V}$ and we have

(2) $\mathrm{M}+\mathrm{M}^{\prime}\left(\mathrm{V}^{\prime} / \mathrm{V}\right)=(1 / \mathrm{V}) \mathrm{PT}$

Thus the betas in text equation (1) correspond to $\left(V^{\prime} / V\right)$. In this context Simon's use of the term "degree of effective circulation" to refer to ( $\left.\mathrm{V}^{\prime} / \mathrm{V}\right)$ and an increase in "hoarding, "to refer to a change in V, seems natural. Perhaps the major difference between Simons and Fisher was Simons's willingness to expand the left side of (1) to include a wide variety of M's.
} 
in the balance sheet for influences on the level of spending and emphasized that liquid assets other than those defined as money were near-moneys or money substitutes." Indeed, McKean [1951, p. 83] believed that Simons "may have exaggerated the significance of near-moneys."

Finally, I should note that Simons did not ignore the credit-intermediation function of banks that has come to play an important role in recent interpretations of the Depression. Simons argued that the Depression was aggravated by the "forced liquidation" of loans as banks scrambled for liquidity. For that reason he advocated restricting banks to long-term investments, thus freeing them from an "illusion of liquidity" (Simons 1948, 328). Simons, however, viewed forced liquidation as part and parcel of the general destruction of the moneyness of near moneys: Banks cut lending during the crisis in order to rebuild their liquidity position, the same reason individuals cut their spending.

The notion that the quality of the money stock needs to be included in any full accounting of monetary phenomena is not unique, of course, to Henry Simons. It is concern about quality, for example, that has motivated many attempts over the years to compute weighted aggregates of the money stock. Typically, however, concern about quality has surfaced in the context of long-term changes in velocity. Bordo and Jonung (1987), for example, investigated a closely related phenomena, the spread of commercial banking, in their international comparison of longterm changes in velocity. What is unique to Simons is his stress on rapid quality deterioration during the banking crises of the 1930s.

\section{Quality Decline and its Effect on the Economy}

The decline in quality was produced by the waves of bank failures in 1931-1933. Its most 
dramatic manifestation was a restriction on withdrawals. One way this occurred was through the enforcement of a notice of withdrawal requirement on a time deposit that would not have been enforced before the crisis. But during 1932 demand deposits were increasingly affected. A bank, either on its own volition or under the shield of a local, state, or eventually, a federal proclamation, would limit cash withdrawals or transfers according to some simple rule: say no more than 5 percent of the account could be withdrawn until further notice.

The channel through which such restrictions would influence economic activity is straightforward: money could not perform its basic function of mediating exchange. Here is how H. Parker Willis and John M. Chapman (1934, pp. 11-12) described the effect of the restrictions.

\footnotetext{
"It was speedily evident that, through lack of currency, the business of several communities was likely to be brought almost to a stop. The issue of some form of local medium of exchange was thus essential, and such a medium was afforded by substitute money of various classes, .... It remained true that, as the holiday spread rapidly over the country, there was less and less possibility of maintaining inter-community trading and exchange of goods. A national currency was lacking."
}

One way of coping with the absence of a medium of exchange is for local communities and private firms to issue scrip, and in fact this was done on a large scale. A number of communities even tried Irving Fisher's plan for stamped money. In principle, the stock of money is understated during this period by the omission of scrip from the standard statistics. But the more important point is that these makeshifts are a sign of the inability of the banking system to provide an adequate medium of exchange.

Although restricted deposits were the most dramatic manifestation of quality 
deterioration, the phenomenon was more general. The threat of restriction or bank failure hung over all deposits, especially those in western and midwestern banks, and reduced the value of deposits as stores of purchasing power for use in emergencies. As a result money holders shifted funds into safe alternatives to deposits.

There were a variety of safe alternatives. (1) Currency. The currency-deposit ratio started to rise sometime after the first banking crisis. As a substitute for deposits, however, currency had its limits. One was simply the limit on the number of safety-deposit boxes. Some depositors withdrew part of their deposits in the form of cash and placed it in safety deposit boxes in the same institution. Once the stock of safety deposit boxes was exhausted, withdrawing cash became a less attractive alternative. Currency was also inconvenient as a substitute for very large deposits in making transactions, particularly interregional transactions. (2) Postal Savings. The ratio of postal savings to deposits behaved in a fashion similar to that of currency. Postal savings, like currency, were an imperfect substitute for large active accounts because postal savings were not subject to check. (3) Treasury Bills. The sharp decline in the yield on treasury bills probably reflects, at least in part, the "flight to quality" as deposit holders attempted to convert their assets into a safer form. The ratio of the yield on 3 month treasury bills to the yield on 20 year treasury bonds fell from 1.4 in September 1929 ( 4.89 percent divided by 3.50 percent) to .56 in June 1930, to .20 in June 1931, to .07 in June 1933, and to .05 in June 1933 . The ratio remained low for the rest of the decade. In June 1939, the ratio was .02 (.05 percent divided by 2.54 percent). (Cecchetti, 1988, 1131-35).

(4) Deposits in safe regions of the country or individual banks with a reputation for soundness. Angell $(1936,66-68)$ notes that the New York and Philadelphia Federal Reserve 
districts gained deposits relative to other districts after 1929. He attributes this to the movement of funds from the interior seeking safety. According to Hoover and Ratchford $(1951,171)$ large insurance and railroad companies transferred working balances from small local banks in the South to larger safer banks nearer their home offices. In Chicago deposits flowed from suburban banks into the Loop banks. To some extent, of course, even without these alternatives one could achieve greater safety by diversify one's portfolio of bank deposits. Presumably, handling one's transactions with accounts in a number of banks would be less convenient, and would require a greater total amount of deposits.

(5) Gold. Even some apparently safe assets, such as federal reserve notes, might appear to some money-holders as less desirable than gold, especially during the final phase of the banking crises. For one thing the international value of federal reserve notes might depreciate.

The existence of these close but imperfect substitutes is adds an important dimension the argument. If consumption was the closest substitute for bank deposits, depositors would increase their spending on goods and services when the quality of deposits fell. If safe assets were a perfect substitute for deposits, then a decrease in quality of deposits would simply produce a one-for-one substitution of alternative assets for deposits. But if the alternatives were a close but imperfect substitute then a decrease in quality would lead to an attempt to build up total liquid balances putting downward pressure on spending.

The following example illustrates the kind of reaction necessary for the last argument to go through. Someone living in the suburbs of Chicago held $\$ 5,000$ in deposits in a local bank and $\$ 1,000$ in cash before the banking crises. After the crises they decided to move say $\$ 4,000$ into a bank in the Loop (keeping $\$ 1,000$ in the local bank) and to increase their cash holdings 
to $\$ 2,000$ to conduct local transactions and to provide additional safety. To accumulate the additional liquid assets they had to cut back current consumption. Separate decisions to increase cash balances then would have had a depressing effect on the economy, would have produced a contraction of bank deposits, and might have prevented the intended accumulation of additional liquid balances.

The story, as I have told it, is cast in terms of a householder; the same story could be told about business deposits. Hoover and Ratchford $(1951,171)$ claim that it is well known that "during depressions large industrial and commercial companies become more liquid as inventories, receivables, etc. are reduced by conversion into cash." Part of this is explained by an increased demand for money occasioned by the risk and uncertainty created by the Depression. But part is explained by the failure of working balances in weak banks to supply as much liquidity as they did before the banking crises.

\section{Restricted Deposits: A Sensitivity Analysis}

A rigorous application of Henry Simons's approach would include restricted deposits in the definition of money, but at a reduced weight reflecting their reduced liquidity. The conventional approach, which weights equally all assets within the monetary aggregate, that I will follow, would exclude restricted deposits because they resemble risky long-term securities more than they resemble deposits convertible on demand into cash. ${ }^{4}$ The standard estimates

${ }^{4}$ The Commercial and Financial Chronicle (February 18, 1933, p. 1132) reported that in Youngstown Ohio the passbooks of local building and loan associations that had restricted withdrawals were being sold like stocks and bonds by licensed brokers. It was said that in Cleveland unlicensed brokers had been buying passbooks at 25 cents to 75 cents on the dollar. The passbooks were worth 100 cents on the dollar when applied to mortgages held by the 
follow neither approach. They exclude restricted deposits after the federal bank holiday in March 1933, but include restricted deposits before that date. Friedman and Schwartz's decision to make no adjustment for restricted deposits before the federal bank holiday is based on the lack of hard numbers. Given the purpose of Friedman and Schwartz -- to show that the decline in the stock of money was a major causal factor in producing the Great Depression -- including or excluding restricted deposits before the federal bank holiday was of little moment. But that battle has been won (at least to the satisfaction of most monetary historians). Attention has turned to secondary and tertiary factors that may have made important but smaller contributions to the crisis. In that context the treatment of restricted deposits before the holiday makes a difference.

Restricted deposits were a phenomenon of 1932, particularly in the Midwest, although they might have appeared somewhat earlier, perhaps after Britain's departure from the gold standard in October 1931. The Minneapolis Federal Reserve, for example, noted in its annual report that

"During 1932 numerous banks in the district declared moratoria on payments to creditors for varying lengths of time. During the moratorium period, agreements were reached for the waiver of immediate payment of deposits, the waiver of a portion of the book value of unsecured deposits, or a combination of these methods of enabling banks to continue in operation." (Annual Report, 1932, 6).

Unfortunately, the extent of restriction, particularly in the early part of 1932, was not well documented. H. Parker Willis and John M. Chapman (1934, p. 7) believed that the press deliberately down played the situation, responding to pressures that Willis and Chapman dated to the formation of the National Credit Corporation (a device promoted by the Hoover administration to provide for mutual aid among the banks).

association. 
Nevertheless, it is possible to form a qualitative idea of the extent and timing of the problem. Some figures are available for Wisconsin where a state law permitted banks to restrict withdrawals or place part of their deposits in trusts or receivership if 80 percent of depositors (fewer if the state banking commissioner permitted it) approved the plan. According to Andersen (1954, p. 172) of the 962 banks existing in Wisconsin in 1929 (including mutual savings banks), only 270,28 percent, avoided any restrictions except during official banking holidays. Of the remainder 20 percent imposed temporary restrictions, 34 percent placed part of their deposits in trusts or receiverships, and 18 percent placed all of their deposits in receivership.

In May of 1932 the Indiana Study Commission on Financial Institutions, a response to a serious situation in that state, surveyed state bank commissioners on the number of banks in their state that restricted withdrawals. The results of the survey are reported in Table 1. About 3.5 percent of the banks reported restrictions on withdrawals on all accounts. The total rises to 5.3 percent if account is taken of restrictions on savings banks. ${ }^{5}$ The banks restricting deposits were small rural banks so the percentage of total deposits restricted would be smaller if all other banks were unrestricted. But banks and bank commissioners were reluctant to report restrictions. The large number reported for Indiana (28 percent), for example, may reflect a special problem in that state, but it may reflect a recognition by the Bank Commissioner that there was no point in trying to make light of a situation that the Study Commission knew at first hand. Upham and Lamke $(1934,12)$ concluded that "it is probable that the figures considerably understate the extent of restrictions."

${ }^{5}$ In general it appears that the second column was distinct from the first. But some states may have misinterpreted the Commission's questions and included the column 2 banks in column 1 . 
Beginning in late 1932 the imposition of restrictions accelerated. This can be seen in Table 2 which chronicles the state and local bank holidays. The first signs were municipal holidays declared in the upper midwest. On November 1 came the first statewide moratorium in Nevada, and on February 12, a one day holiday in Louisiana. The final dissolution of the banking system was ushered in by the holiday declared in Michigan in mid-February. Most of the larger Michigan banks belonged to one of two holding companies and the smaller Guardian Detroit Union Group was teetering on the edge of bankruptcy. A desperate effort was launched to save this group through a Reconstruction Finance Corporation loan combined with aid from the Ford interests. But the plan foundered on demands that the Reconstruction Finance Corporation hold adequate collateral for its loan and the unwillingness of Henry Ford to take part. ${ }^{6}$

The final spurt of holidays was caused, in part, by the fear that holidays in neighboring states would lead to unsustainable withdrawals in states that dared to keep their banks open. Governor Ruby Lafoon of Kentucky undoubtedly spoke for many when he declared a bank holiday on March 1, 1933. His proclamation, given here, also describes the nature of the restrictions typically imposed.

"Whereas many banks in the cities and towns contiguous to the borders of the State of Kentucky are closed or are only permitting limited withdrawals of their deposits.

"Whereas, a result of this situation will be that the funds of the banks of Kentucky will be withdrawn to supply the needs of these other communities, thus weakening the resources of the people of the Commonwealth, and,

"Whereas legal holidays may only be declared in the State of Kentucky by the Governor appointing certain days as days of thanksgiving.

"Now, therefore in consideration of the nation-wide banking situation and in view of the

\footnotetext{
${ }^{6}$ See, for example, Arthur A. Ballantine (1948). Ballantine, the Under Secretary of the Treasury, took part in the negotiations with Henry Ford.
} 
fact that the people of the State of Kentucky, though suffering from the general depression, may perhaps in comparison with the people of other states have reason for thanksgiving.

"I as Governor of the State of Kentucky, appoint the days of March 1, 2, 3 and 4 1933, as days of thanksgiving in the State of Kentucky and declare such days legal holidays and do further provide as follows:

"(1) That during said holidays all banks and trust companies shall be closed in the State of Kentucky for the regular transaction of business except.

"(a) Said banks and trust companies may during the ordinary business hours of said holiday pay to their depositors (whether time or demand) not exceeding an aggregate of $5 \%$ of the respective deposits of such depositors at close of business on Feb. 28, 1933, provided that such payments shall only be made on checks, drafts or receipts dated subsequent to Feb. 28, 1933.

"(b) During the banking hours of the last there days of the holiday period, said banks and trust companies may accept new deposits but such deposits shall be held in trust funds and may be insofar as they are represented by deposits of cash, withdrawn in full during said period.

"(c) During said holiday period, said banks and trust companies, may transact any and all other business which does not involve the paying out of deposited funds other than herein authorized.... (Commercial and Financial Chronicle, March 4, 1933, 1484-85).

It is obvious from table 2 that by late February or early March 1933 a large fraction of deposits had been restricted by official actions and a good portion of the remainder had been restricted in some measure by individual bank actions. Table 3 , makes this point in a slightly different way by showing a snapshot of the banking system on the eve of President Roosevelt's announcement of the national banking holiday. Virtually all deposits in the country were subject in some measure to restriction. It is clear that the meaning of money had changed a great deal from 1929 when a dollar in bank deposits was as good as gold.

One way to take account of this history would be to add a series of dummy variables to a regression explaining the Depression. Although this approach has the advantage that it sharply separates the existing data, however imperfect, from my machinations, it has the disadvantage that one would have to use a large number of dummies to incorporate all of the qualitative information. As a result the regressions would be difficult to interpret. Instead, I have utilized the qualitative information to make an experimental adjustment to M1. Friedman and Schwartz 
$(1982,217)$, to invoke the voice of authority, followed a similar approach for similar reasons to take into account the growing financial sophistication in the United States after the Civil War in their attempt to estimate the long-term demand for money.

My adjustment was based on two assumptions. (1) I assumed that the restricted deposits recorded after the national bank holiday represented the statistical unveiling of a problem that had grown throughout 1932. So I took the ratio of unrestricted to total deposits on March 29, 1932 (.88), projected this ratio back to 1 in January 1932 by increasing the ratio a constant percentage each month, and then applied this ratio to the standard estimate of deposits. ${ }^{7}$ This procedure, incidentally, yields a ratio of unrestricted deposits to total deposits of about .964 in May of 1932, not far off the ratio of unrestricted banks to total banks (.965) estimated by the Indiana Commission.

(2) To take account of the state and local bank holidays in February and March 1933 I reduced the estimated ratio of unrestricted to total deposits further to .5 in those months. The rationale was that since February began with a relatively modest fraction of restricted deposits and ended with nearly all deposits restricted, an estimate of the ratio of restricted to total deposits designed to simulate a daily average would fall about midway between 0 and 1 . A similar logic would apply to March. The monetary aggregate incorporating adjustments (1) and (2) is referred to below as Mla.

While one could argue about the particular assumptions I have made -- the results of some more complicated alternatives are noted below -- there can be little doubt that in a broad sense M1a corresponds more closely to a meaningful economic total than does M1. The money

\footnotetext{
${ }^{7}$ Friedman and Schwartz $(1963,430)$.
} 
stock was clearly smaller in February 1933, when nearly all deposits were frozen by the end of the month, and when there was great uncertainty about whether there would ever be access to those deposits, than it was in April 1933 when the amount of restricted deposits was smaller, when it could be assumed that most of those deposits would soon be released, and when confidence in the banking system in general had increased as a result of the measures taken by the Roosevelt administration.

Because fluctuations in the macroeconomy were extremely violent in this period, substituting M1a for M1 can make a noticeable difference in equations intended to explain the interwar period. Precisely how to formulate such a regression, however, is a matter of controversy. Rather than try to estimate my own equation from (my) first principles, I have simply used the well-known equations estimated by Bernanke (1983) except that I have used the actual growth in the money stock rather than an estimate of the unanticipated growth. As Haubrich (1990, 234-35), who uses a similar approach, explains in his study of Canada, the need for comparability with other studies suggests using simply the actual growth rate of money.

Bernanke attempted to explain industrial production and included as explanatory variables lagged values of the rates of change of industrial production, current and lagged values of rates of change of money, and variables intended to capture the increased costs of credit intermediation. Anna J. Schwartz (1981) ran similar regressions to test whether money Grangercaused debits to deposit accounts, a proxy for nominal GNP. My procedure is to see whether I can improve a base equation of this sort by taking the quality of the money stock into account.

Table 4 shows several tests of M1a. The first two columns show the effect of replacing M1 with M1a in an equation that explains changes in industrial production with contemporaneous 
and lagged values of changes in industrial production and money. ${ }^{8}$ The incremental R2 from replacing $\mathrm{M} 1$ with $\mathrm{M} 1 \mathrm{~A}$ is .07 and an additional lagged change in the money stock is significant.

Column (3) adds two variables -- DBANKS the change in the deposits of suspended banks deflated by the wholesale price index and DFAILS the change in the liabilities of bankrupt corporations deflated by the same index -- that Bernanke introduced to measure the cost of credit intermediation. (These variables, of course, may also be picking up the decline in the quality of deposits.) These variables were included first because Bernanke's work and that of subsequent researchers suggest that they belong there, and because they provide a basis for judging the ability of a revised monetary series to improve the base equation. The incremental $\mathrm{R} 2$ from the credit-intermediation variables is .02 . The additional information appears to be carried by the contemporaneous rate of business failure (DFAILS).

Column (4) uses an alternative index of industrial production constructed by Miron and Romer $(1990,337)$. This variable is explained less well, the $\mathrm{R} 2$ is only .13, and the variables representing the cost of credit intermediation don't add any information after my adjustments to the money stock.

Industrial production, a real variable, is not entirely appropriate in a quantity theory framework, and may not be representative of broader movements in real output. Bank clearings (used by Schwartz) is normally highly correlated with GNP, but might be distorted in some months by the bank crises. And personal income (an alternative nominal variable used by Schwartz) is not available until 1929. So I experimented with a number of other dependent

\footnotetext{
${ }^{8}$ Data on industrial production, wholesale prices, and department store sales is from Moore (1961, 184-89, 144, 133). Monetary variables are from Friedman and Schwartz (1970, 16-33).
} 
variables such as various indexes of economic activity, and Geoffrey Moore's index of contemporaneous indicators. Column (5) reports results for one, department store sales. This variable was chosen because it has the highest correlation at the quarterly level with nominal GNP of all of the variables I tried. Although it would seem peculiar nowadays to use this variable to represent broad movements in the economy, it must be remembered that department stores played a more important role in the distribution system than they now do. It probably corresponds to what is now called retail sales. Here again substituting M1a for M1 makes a substantial difference. The incremental R2 from replacing M1 with M1a is about .13. Adding the cost of credit intermediation leaves the R2 unchanged and only the lagged value of DBANKS is significant.

Alternative assumptions about the behavior of restricted deposits produce similar results. For example, it could be argued that since the Friedman and Schwartz estimates are centered on the last wednesday of the month during this period $(1970,499)$ it is inappropriate to adjust the figures for March to reflect the bank holidays: unrestricted deposits are correctly measured on the last wednesday. But when the equations are re-estimated with a money stock that adjusts for restricted deposits through February and then uses the standard M1 estimates for March and succeeding months, the results are almost identical in terms of R2 and significance of the coefficients.

It could be argued, along the lines suggested by Friedman and Schwartz $(1963,433)$, that some of the deposits restricted after the federal bank holiday should be included in the monetary aggregates. But an experiment in which I included one half of restricted deposits in the months following the banking crisis again produced very similar results. The $\mathrm{R} 2$ was marginally higher, 
.407 in the analog of equation (3) compared with .382. But the coefficients told a similar story; among the credit-intermediation variables only the lagged value of DFAILS was significant.

Evidently, from a statistical point of view, my crude adjustment to the money stock has much the same effect as the DBANK and DFAILS variables -- to help the equation explain the period around the federal bank holiday. ${ }^{9}$ If the regressions can be trusted -- and are not simply picking up the effect of more fundamental variables on money, industrial production, etc. -- then it would be fair to conclude that both the decline in the quality of the money stock and the increased cost of credit intermediation played some role in depressing the economy below the level that could be explained by conventionally measured monetary aggregates.

\section{Safe Substitutes for Deposits}

My preference is for the estimates in section 3. But the importance of quality deterioration can be confirmed in another way. A more conventional approach to measurement error is to include additional variables in the regression that are thought to be correlated with the error. In this section I use the ratio of safe monetary assets to deposits to proxy for quality.

The following theoretical rational helps to justify this approach. The standard quantity theory asserts that people want to hold a certain fraction $(\mathrm{k})$ of their nominal income $(\mathrm{Y})$ in the form of a simple sum of monetary assets (M). Assume instead that people want to keep a fraction of their nominal income in the form of liquidity services generated by deposits (D) and a safe alternative, say currency (C), and that liquidity services are generated by a constant-

${ }^{9}$ I have not done any formal statistical testing of the residuals but it is evident from an inspection that the residuals are far from white noise, and considerable room for improvement in the explanatory regression remains. 
elasticity-of-substitution production function. Then the modified quantity theory can be written as

(3) $\left[(\phi \mathrm{D})^{-\alpha}+\mathrm{C}^{-\alpha}\right]^{-1 / \alpha}=\mathrm{kY}$

where $\phi$ is an index of the quality of deposits, a number varying between 0 and 1 , and $\sigma=1 /(1+\alpha)$ is the elasticity of substitution. The relationship to the standard version of the quantity theory can be seen by noting that as $\sigma$ approaches infinity and $\phi$ approaches 1 equation

(3) approaches

(4) $C+D=k Y$

the standard Cambridge quantity theory. Taking logarithms of both sides of (3), taking derivatives with respect to time, and rearranging terms yields

(5) $g \mathrm{Y}=[\phi \mathrm{D} / \mathrm{Y}]^{-\alpha}(\mathrm{g} \phi+\mathrm{gD})+[\mathrm{C} / \mathrm{Y}]^{-\alpha} \mathrm{gC}$

where $\mathrm{g}$ in front of a variable indicates its percentage rate of change.

To substitute out $\mathrm{g} \phi$ we can make use of the assumption that people will try to minimize the amount of monetary assets they purchase by setting the marginal product of currency equal to the marginal product of deposits (assuming that they exchange at a price of one dollar of deposits for one dollar of cash). This yields,

(6) $\mathrm{C}^{-1-\alpha}=\phi^{-\alpha} \mathrm{D}^{-1-\alpha}$

Taking the logarithmic time derivative of (6) and using the elasticity of substitution yields,

(7) $\mathrm{g} \phi=[1 /(1-\sigma)](\mathrm{gC}-\mathrm{gD})$

which shows that the decline in quality of deposits is a simple linear function of the increase in the currency-deposit ratio.

Substituting (7) into (5), noting that the sum of currency and deposits is the measured 
money stock, and rearranging terms yields,

(8) $\mathrm{gY}=\mathrm{gM}+[1 /(1-\sigma)](\mathrm{gC}-\mathrm{gM})$

So in this extension of the quantity theory the percentage growth of income will be a linear function of the growth of the measured stock of money and the growth of the currency-money ratio.

As noted in section 2, there were a number of safe alternatives to bank deposits that could be used as the theoretical counterpart of $\mathrm{C}$ in equation (8). Figure 1 illustrates the behavior of three ratios: currency to M1, postal savings to M1, and deposits in New York City banks to M1. As you can see, each ratio behaves in a broadly similar fashion. The main difference is that the currency-money ratio drops off rather sharply after the federal bank holiday while the other ratios remain on a higher plateau. Although I tried all of these variable, the basic story, as might be expected from the figure, can be told by settling on one ratio. In the results reported in Table 5 I use one minus the ratio of currency plus postal savings to M1 to proxy for "quality." Equation (2) adds quality and quality lagged one period to base equation (1). The incremental R2 of the quality variables is .022 and contemporary quality is significant. The monetary variables, however, are less significant than in (1), perhaps because of colinearity with the quality variable. The incremental $\mathrm{R} 2$ from then adding the variables intended to measure the cost of credit intermediation, as shown by equation (3), is .061 and contemporaneous values of both proxies are significant. The quality of money variable remains only marginally significant. Although, to reiterate a point made above the DBANKS variable may also be picking up the decline in the quality of the money stock.

The Miron-Romer index of industrial production is the dependent variable in equation 
(4). Here, as in the tests of the money stock adjusted for restricted deposits, the R2 is lower than for the older index of industrial production. Neither the quality variables, nor the cost-of-creditintermediation variables are significant.

Department Store Sales is the dependent variable in equation (5). In this test the contemporaneous values of both the quality variable and DBANKS are significant. DFAILS are less significant in this equation. Also as might be anticipated from an equation more in the spirit of equation (8) -- the dependent variable is nominal -- the money variables are stronger.

During the final banking crisis depositors focussed not simply on converting deposits into postal savings, federal reserve notes and so on, but more specifically on gold. ${ }^{10}$ Table 6 reports regressions in which the quality variable is defined as the ratio of gold outside the Treasury to the total money supply. ${ }^{11}$ It covers only the period up to December 1933 since there was (officially) no gold held by the public after this date. The results are similar to those reported in previous tables. Adding the gold-money ratio significantly improves the fit of the equation. The credit-intermediation variables also come in strongly. Both quality and credit intermediation help explain department store sales, although in this equation the business-failure variables do not come in significant.

All in all I conclude that the evidence from regressions using ratios of safe money to total money to capture the decline in the quality of deposits, like the evidence from experimental adjustments to the money stock, show that quality deterioration depressed spending and added to the magnitude of the contraction.

\footnotetext{
${ }^{10} \mathrm{I}$ am indebted to Michael Edelstein and Richard Sylla for pointing this out to me.

${ }^{11} \mathrm{~A}$ more refined estimate would make an allowance for gold held by banks.
} 


\section{Consistency with the Experience in Other Financial Crises}

If quality deterioration was important in the Great Depression we would expect to find that it was important in other crises. This appears to be the case. Grossman (1993), who investigated the late nineteenth century, finds that even a relatively small bank-failure shock could lead to a 2 percent fall in real GNP and that a major shock could lead to a 20 percent fall. Perhaps the most troubling cases from a quality-of-money perspective are those financial panics (1890 and 1914) that accompanied relatively mild contractions in economic activity. (Cagan, $1965,266)$.

In a number of nineteenth-century panics suspension of specie payments produced markets in which specie was quoted at a premium in terms of deposits. In such cases a money stock in which deposits were valued at their specie price, and would therefore be consistent with the pre-panic money stock, would be smaller than the conventionally measured stock in which both deposits and specie were counted at their nominal values. In their discussion of the Panic of 1893 one such episode, although Friedman and Schwartz, although they do not advocate adjusting the monetary aggregates for the currency premium, do argue $(1963,110)$ that restriction "also reduced the usefulness of deposits," and that "this made the given nominal stock of money equivalent to a smaller stock with free interchangeability."

Sprague (1977 [1910], 200) writes the following with reference to the crisis of 1893.

"suspension was a potent factor accentuating the depression in trade which characterized the month of August. It increased the feeling of distrust ... A more definite consequence was the difficulty in securing money for pay rolls which led to the temporary shutting down of many factories. Finally, it deranged the exchanges between different parts of the country, causing a slackening in the movement of commodities and needless delays in collections which were already slow on account of the general situation." 
Note the similarity between Sprague's description of the effects of the Crisis of 1893 and the Willis-Chapman description, quoted in section 2 , of the problems generated even before the federal bank holiday by restrictions on deposits -- "A national currency was lacking."

Something similar seems to have happened during the Panic of 1907 . Friedman and Schwartz $(1963,157)$ note that

"In October [1907] came the banking panic, culminating in the restriction of payments by the banking system ... The contraction simultaneously became much more severe. Production, freight car loadings, bank clearings, and the like all declined sharply and the liabilities of commercial failures increased sharply. Restriction of payments by banks was lifted in early 1908, and a few month thereafter recovery got underway."

Although Sprague argues that the derangement of the economy was less in 1907 than in 1893, in part because bankers had learned how to cope with restriction by introducing substitutes for customary forms of money, he does note (1977 [1910], 302) that some of the same difficulties emerged.

Recently Bernanke and James (1991) completed an international comparison of impacts of the Great Depression. Here they introduced dummy variables for periods in which a country experienced a banking crisis into regressions explaining industrial production.

They found that industrial production fell more in countries that experienced crises. Their explanation stresses credit-intermediation effects. But it is possible that in some of these cases a decrease in the ability of the money stock to satisfy the transactions and precautionary motives for holding money may have played a role as well.

\section{Contrasts with other Interpretations of the Great Depression}

On a purely theoretical level bank failures play a surprisingly ambiguous role in 
Friedman and Schwartz's account of the Great Depression. According to Friedman and Schwartz there are two effects of bank failures, one on the supply of money and one on the demand for money. Consider first the supply effect. A threat of bank runs and failures will induce the public to convert deposits into currency, reducing the stock of money. The threat will also induce banks to try to convert other bank assets into reserves. Again the effect will be to reduce the stock of money. The effect of failures on the stock of money is to reduce it, thus putting a strong deflationary pressure on the economy.

But now consider the effect on the demand for money. The threat of widespread failures can be interpreted as an expected loss from holding money, so the rational response will be to try to spend it as rapidly as possible, velocity will rise and the effect will be inflationary. Thus the emergence of a threat to the safety and soundness of the banking system produces two opposing effects: on the one hand it reduces the stock of money, but on the other it raises velocity. From a purely theoretical point of view there is little we can say. We know that the supply effects dominated the demand effects from empirical evidence. The period 1920 - 1933 was one of falling rather than rising real incomes and prices. The intuitive appeal of the Friedman-Schwartz argument rests, I believe, on the fact that it can be verified in a simple thought experiment. Suppose you go to sleep thinking that your bank deposits are perfectly secure and wake up to learn that there is some risk, say 5 percent, that the bank in which you hold your deposits may fail, and that if it does you will lose everything. What will you do? One thing you might do is convert deposits into currency, hence the decline in the deposit-currency ratio, and the downward pressure on the demand for money. The other thing you might do is increase your purchase of goods and services; hence the positive effect on the 
flow of spending.

But there are other possibilities. Suppose that by diversifying your deposits among a number of banks (for this purpose currency can be considered another bank with no risk of failure but rather inferior services) thus converting a gamble consisting of a probability of .05 of losing everything into a certain loss of 5 percent of capital. Then our representative individual might behave much like an individual who had simply lost 5 percent of his deposits, by reducing consumption in order to rebuild his cash position.

Friedman and Schwartz make their case primarily on the basis of a comparison with Canada. (Friedman and Schwartz 1963, 352-53) The fall in the money stock was similar in the U.S. and Canada, but the fall in velocity was less in the United States. Since Canada did not suffer from bank failures Friedman and Schwartz concluded that velocity fell less in the United States because people were forced to spend by a fear of bank failures. There may, of course, be other explanations for the difference between the United States and Canada. For example, it may be appropriate to view Canada as a small part of a large North American economy dominated by the United States. Then it would not be surprising if the fall in GNP in Canada and the United States were of roughly similar percentages, despite differences in the fall in money, especially during the period of fixed exchange rates.

Haubrich's results for Canada support this explanation. Haubrich $(1990,250)$ found that the "contraction of the Canadian banking system, whether measured by branches, [bank] stock prices, loans, or commercial failures, did not significantly influence the Canadian economy." This is consistent with the quality interpretation. There were no bank failures in Canada, and no restriction of deposits. A dollar of deposits remained essentially equivalent to cash throughout 
the 1930s.

After 1933 the quality of the money stock in the United States improved rapidly. One of the most obvious changes was the introduction of deposit insurance. One could now afford, for example, to consolidate and reduce deposit balances, spend hoarded currency, and still maintain the same protection against a rainy day. Just as the decline in the quality of money contributes to explaining the severity of the decline in income before 1933; the rise in the quality of money can explain part of the rapid rebound.

In A Monetary History Friedman and Schwartz note that the (measured) stock of money fell until 1934 while the economy rebounded rapidly. Friedman and Schwartz (1963, 433-34) attribute this to a rise in velocity, prompted in part by the "confidence" generated by the emergency revival of the banking system. But if the banking crisis raised velocity, why didn't ending the crisis reduce velocity? By treating bank failures and deposit insurance as quality determining variables we get an explanation that is consistent across the great contraction and the rebound in 1933-1934.

In Lessons from the Great Depression Peter Temin $(1989,49-52)$ argues that the banking crises did not contribute to the Depression through a monetary channel because interest rates declined. If there had been a genuine shortage of money, people would have tried to rebuild their cash balances, Temin argues, by selling securities such as treasury bills and this would have produced an increase in yields. ${ }^{12}$

The quality perspective provides an explanation. The shortage was of liquid assets, not

\footnotetext{
${ }^{12}$ Temin was writing particularly in the context of the First banking crisis; I am assuming that the argument could be generalized to the whole of the period 1930-33.
} 
deposits (which were no longer liquid) and so there was a flight to gold, treasury bills, and similar assets. In other words, lower yields. The "flight to quality" has been noted by a number of writers. The advantage of discussing it in terms of the quality of the money stock is that this terminology helps to link the flight to quality to other aspects of the banking crisis. For example, quality decline in the money stock also provides a simple way of explaining the otherwise confusing high level of real balances observed in 1932 and 1933: measured real balances were high but quality-constant real balances were low.

Ben Bernanke (1983), as we noted above, has offered a supplementary explanation for the depths reached in the Depression. The banking crisis and the deflation damaged the main source of credit for farmers and small businesses. Banks had information about specific borrowers, a form of capital, and banks relied on collateral to overcome the asymmetric information problem. ${ }^{13}$ The failure of banks, and the erosion of the net worth of borrowers, made it difficult for traditional borrowers from banks to get credit. As a result such borrowers were forced to cut back their spending. Bernanke, as we have seen, offered regressions in which real deposits of failed banks and real liabilities of failed businesses were used to proxy for damage to the credit mechanism. Recently, Grossman (1993), as we noted above, showed that bank failures were important during the National Banking Era, and followed Bernanke in interpreting this as a non-monetary credit intermediation channel.

Bernanke's regressions, however, can be regarded as reduced form equations. (Temin 1989, 53). It is conceivable that Bernanke's variables, in particular as we have noted above, the

\footnotetext{
${ }^{13}$ (Calomiris 1992) is an excellent survey of the research that resulted from Bernanke's paper.
} 
real deposits of suspended banks, in part may be picking up other forces such as the decline in the quality of the money stock.

\section{Conclusion}

In the end we reach a conclusion that seems obvious once attention is drawn to it: the banking crises probably contributed directly to the depth and duration of the Great depression. Both a transaction channel and a portfolio adjustment channel were involved. The restrictions on withdrawals that proceeded the federal bank holiday destroyed the ability of the banking system to provide a uniform national currency, disrupting commerce and industry. Moreover, by reducing the ability of bank money to serve as a temporary abode of purchasing power, the collapse of the banking system encouraged people to purchase safe assets (gold, national bank notes, government bonds, deposits in well regarded banks, and so on). In attempting to do so they reduced current purchases of real goods and services, putting downward pressure on real output and prices.

The point, to put it slightly differently, is that the quantity theory needs to be modified. Assume that people wish to hold a quality-constant money supply in proportion to their income. Then we can view the quantity theory that applies in normal times as a special case of this more general model, the special case where the quality index is one.

Our experience with severe banking and monetary crises is so limited that we will never have an explanation of the Depression that can win out against all others on purely statistical grounds. In the end we will have to be content with an explanation that best fits the facts, but possesses other criteria -- simplicity, plausibility, consistency with theoretical explanations, and 
so on. On these grounds it seems to me that a monetary explanation, modified to take into account the decline in the quality of the money stock, is still the most convincing explanation of the Great Depression.

\section{References}

Amdersen, Theodore A. 1954. A Century of Banking in Wisconsin. Madison: State Historical Society of Wisconsin.

Angell, James W. 1936. The Behavior of Money: Exploratory Studies. New York: McGraw-Hill Book Company, 1936. Reprinted by Augustus M. Kelley, 1969.

Ballantine, Arthur A. 1948. "When All the Banks Closed." Harvard Business Review 26: 129 - 43.

Bernanke, Ben. 1983. "Nonmonetary Effects of the Financial Crisis in the Propagation of the Great Depression." American Economic Review 73: 257-76.

Bernanke, Ben and Harold James. 1991. "The Gold Standard, Deflation, and Financial Crisis in the Great Depression: An International Comparison." In R. Glenn Hubbard, ed., Financial Markets and Financial Crises. Chicago: University of Chicago Press, 33-68.

Bordo, Michael D. and Lars Jonung. 1987. The Long-run Behavior of the Velocity of Circulation: The International Evidence. New York: Cambridge University Press.

Cagan, Phillip. 1965. Determinants and Effects of Changes in the Stock of Money, 1875-1960. New York: Columbia University Press, for the NBER.

Calomiris, Charles W. "Financial Factors in the Great Depression." (August 1992, forthcoming in the Journal of Economic Perspectives).

Cecchetti, Stephen G. "The Case of the Negative Nominal Interest Rates: New Estimates of the Term Structure of Interest Rates during the Great Depression." Journal of Political Economy 12 (1988): 1111-1141. 
Friedman, Milton. 1969. "The Monetary Theory and Policy of Henry Simons." In The Optimum Quantity of Money and Other Essays, 81-94. Chicago: Aldine Publishing Company.

Friedman, Milton and Anna J. Schwartz. 1963. A Monetary History of the United States. Princeton: Princeton University Press.

1970. Monetary Statistics of the United States: Estimates, Sources, Methods. New York: Columbia University Press, for the NBER.

1982. Monetary Trends in the United States and the United Kingdom: Their Relation to Income, Prices, and Interest Rates, 18671875. Chicago: University of Chicago Press.

Grossman, Richard S. 1993. "The Macroeconomic Consequences of Bank Failures under the National Banking System." Explorations in Economic History 30: 294-320.

Haubrich, Joseph G. 1990. "Nonmonetary Effects of Financial Crises: Lessons from the Great Depression in Canada." Journal of Monetary Economics, 25: $223-52$.

Hoover, Calvin B. and B.U. Ratchford. 1951. Economic Resources and Policies of the South. New York: The Macmillan Company.

McKean, Roland. 1951. Liquidity and a National Balance Sheet. In Readings in Monetary Theory, eds. Friedrich A. Lutz and Lloyd W. Mints, 6388. Homewood, Illinois: Richard D. Irwin, Inc. Reprinted from The Journal of Political Economy, 57 (1949): 506-22.

Miron, Jeffrey A. and Christina D. Romer. 1990. "A New Monthly Index of Industrial Production, 1884-1940." Journal of Economic History 50 (June): 321-338.

Moore Geoffrey H. 1961. Business Cycle Indicators. Volume II, Basic Data on Cyclical Indicators. Princeton: Princeton University Press, for the NBER.

Ninth Federal Reserve District, Minneapolis. 1932. Eighteenth Annual Report to the Federal Reserve Board. 
Patinkin, Don. 1972. "The Chicago Tradition, The Quantity Theory,

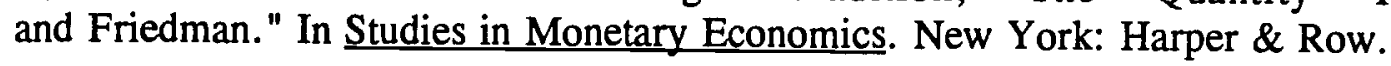

Rockoff, Hugh. 1993. "Henry Simons and the Quantity Theory of Money." (mimeo)

Schwartz, Anna J. 1981. "Understanding 1929-33." Karl Brunner, ed., The Great Depression Revisited. Boston: Martinus Nijhoff.

Simons, Henry C. 1948. Economic Policy for a Free Society. Chicago: University of Chicago Press.

Sprague, O.M.W. 1977 [1910]. History of Crises Under the National Banking Act. Fairfield, NJ: August M. Kelley; reprint, Washington: GPO, National Monetary Commission.

Temin, Peter. 1976. Did Monetary Forces Cause the Great Depression? New York: Norton.

MIT press.

1989. Lessons from the Great Depression. Cambridge:

Upham, Cyril B. and Edwin Lamke. 1934. Closed and Distressed Banks: A Study in Public Administration. Washington D.C.: The Brookings Institution.

Willis, H. Parker and John M. Chapman. 1934. The Banking Situation: American Post-War Problems and Developments. New York: Columbia University Press. 


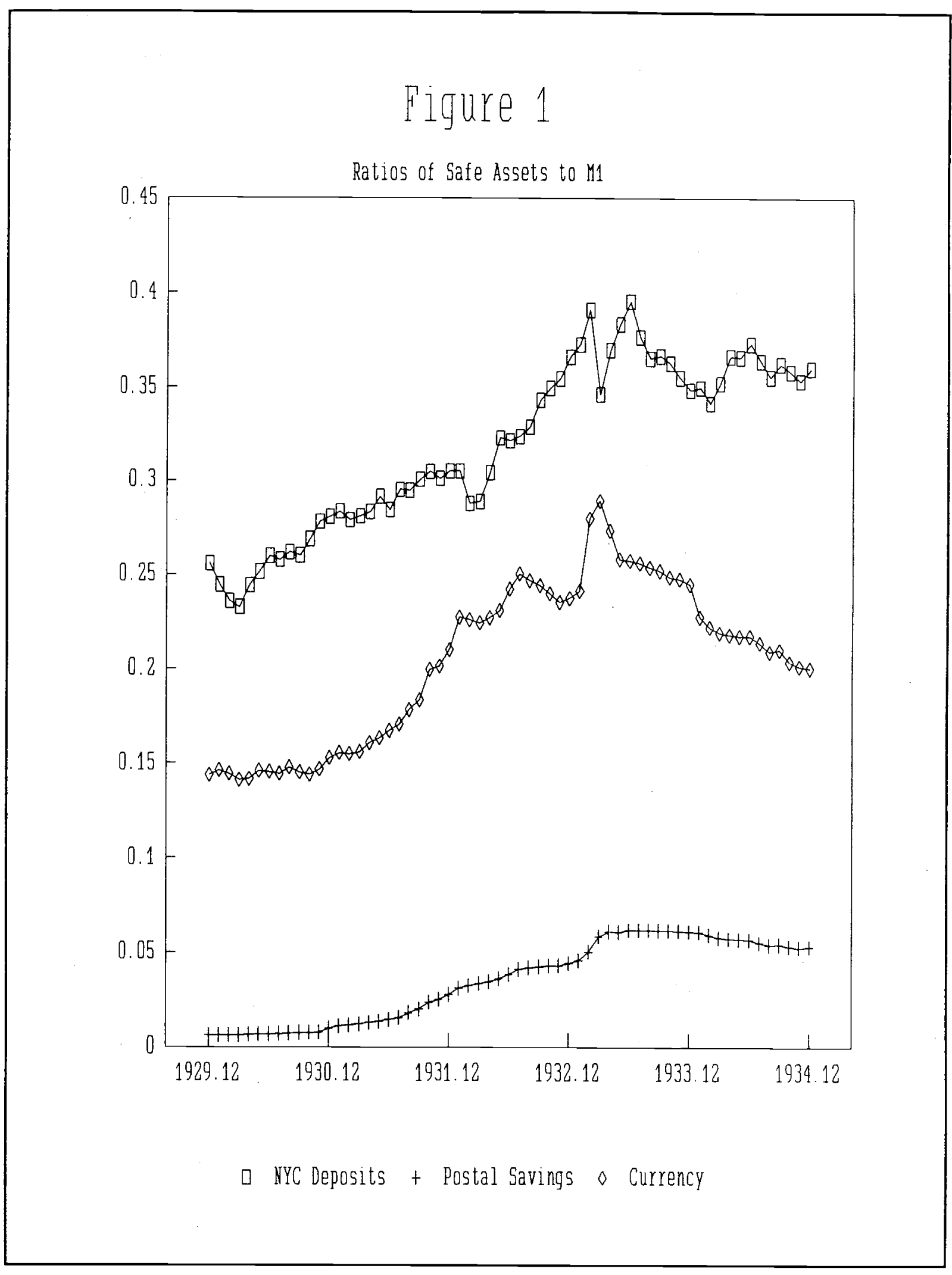




\begin{tabular}{|c|c|c|c|}
\hline \multicolumn{4}{|c|}{ Table 1} \\
\hline \multicolumn{4}{|c|}{ Banks Restricting Deposits, May, 1932 (a) } \\
\hline State & Number of Banks & $\begin{array}{l}\text { Banks with Restricted } \\
\text { Withdrawals on all } \\
\text { Accounts }\end{array}$ & $\begin{array}{l}\text { Banks with Restricted } \\
\text { Withdrawals on Savings } \\
\text { Accounts }\end{array}$ \\
\hline Alabama & 220 & 1 & \\
\hline Arkansas & 329 & 2 & 1 \\
\hline Colorado & 150 & 4 & 2 \\
\hline Connecticut & 191 & & 50 \\
\hline Delaware & 45 & & (b) \\
\hline Georgia & 323 & 1 & \\
\hline Idaho & 96 & $\underline{-}$ & \\
\hline Illinois (c) & 1221 & $\ldots$ & $\ldots$ \\
\hline Indiana & 705 & 200 & (d) \\
\hline Kansas & 806 & & \\
\hline Kentucky & 419 & 20 & 20 \\
\hline Louisiana & 191 & 1 & 2 \\
\hline Maine & 79 & & \\
\hline Michigan & 639 & 50 & \\
\hline Minnesota & 752 & 50 & 2 \\
\hline Mississippi & 280 & 6 & 40 \\
\hline Missouri & 1110 & 12 & \\
\hline Montana & 122 & 7 & \\
\hline Nebraska & 602 & & \\
\hline New Hampshire & 65 & & 3 \\
\hline New Mexico & 27 & & \\
\hline New York & 566 & & 4 \\
\hline North Dakota & 254 & & \\
\hline Oklahoma & 320 & 8 & \\
\hline Rhode Island & 25 & & \\
\hline South Carolina & 138 & & 56 \\
\hline South Dakota & 279 & 5 & 5 \\
\hline Tennessee & 380 & & \\
\hline
\end{tabular}




\begin{tabular}{||l|l|l|l||}
\hline Texas & 700 & 50 & \\
\hline Vermont & 58 & 1 & \\
\hline Virginia & 306 & 11 & \\
\hline Washington & 228 & & 6 \\
\hline West Virginia (e) & $\ldots$ & $\ldots$. & $\ldots$ \\
\hline Wisconsin & 781 & 19 & 19 \\
\hline Wyoming & 58 & & \\
\hline TOTAL & 12465 & 448 & 210 \\
\hline
\end{tabular}

Source: Upham and Lamke, p. 13.

(a) Report of the Indiana Study Commission for Financial Institutions, p. 83. Data compiled from questionnaires sent to the 48 state banking departments. No replies were received from 13 states.

(b) Usual notice required.

(c) The Banking Department of lllinois could give no detailed information as to any restrictions but it is known that some banks in that state took that step. Examples are the institutions of Urbana and Aurora.

(d) Uncertain.

(e) No definite information as to the actual number of banks on a restricted basis. Practically all the banks in the Northwestern part of West Virginia adopted the rule of restricted withdrawals. All banks in Martinsburgh adopted the rule; also banks in Parkersburg and Wheeling.

\begin{tabular}{|c|c|c|}
\hline \multicolumn{3}{|c|}{ Table 2} \\
\hline \multicolumn{3}{|c|}{ Local Bank Holidays in 1932-33 } \\
\hline Date & State & Action Taken \\
\hline 17 October & Minnesota & Municipal holidays declared \\
\hline 1 November & Nevada & 12 day moratorium; twice renewed \\
\hline January & $\begin{array}{l}\text { Illinois } \\
\text { lowa }\end{array}$ & Small towns declare local holidays \\
\hline 20 January & Iowa & One-day Bank Holiday \\
\hline 12 February & Louisiana & One-day holiday \\
\hline 14 February & Michigan & $\begin{array}{l}\text { 8-day holiday, renewed until federal } \\
\text { holiday }\end{array}$ \\
\hline \multirow[t]{2}{*}{20 February } & New Jersey & $\begin{array}{l}\text { Legislature authorizes banking } \\
\text { commission to declare a moratorium } \\
\text { on February } 21 \text { this power is exercised } \\
\text { for one bank }\end{array}$ \\
\hline & Missouri & $\begin{array}{l}\text { One bank restricts withdrawals after } \\
\text { mayor declares moratorium }\end{array}$ \\
\hline
\end{tabular}




\begin{tabular}{|c|c|c|}
\hline 23 February & New Jersey & $\begin{array}{l}\text { Limited withdrawals authorized at two } \\
\text { banks }\end{array}$ \\
\hline \multirow[t]{3}{*}{25 February } & Maryland & 3-day holiday, subsequently extended \\
\hline & Ohio & Banks self-declare holidays \\
\hline & Missouri & $\begin{array}{l}\text { Banks granted right to restrict } \\
\text { withdrawals }\end{array}$ \\
\hline 27 February & $\begin{array}{l}\text { Indiana } \\
\text { Ohio } \\
\text { North. Kentucky }\end{array}$ & $\begin{array}{l}\text { Banks restrict withdrawals under the } \\
\text { authority of new banking laws }\end{array}$ \\
\hline 28 February & $\begin{array}{l}\text { Arkansas, } \\
\text { Pennsylvania }\end{array}$ & Banks initiate restrictions \\
\hline \multirow[t]{2}{*}{1 March } & Philadelphia and Pittsburgh & Individual banks self-declare holidays \\
\hline & $\begin{array}{l}\text { Kentucky } \\
\text { Mississippi Tennessee }\end{array}$ & Bank holidays \\
\hline 2 March & $\begin{array}{l}\text { Alabama California } \\
\text { Georgia Louisiana Mississippi } \\
\text { Nevada, Oklahoma Oregon, Texas } \\
\text { Utah, Washington } \\
\text { Wisconsin }\end{array}$ & Bank holidays \\
\hline 3 March & $\begin{array}{l}\text { Arizona, Georgia } \\
\text { Idaho, Illinois } \\
\text { New Mexico } \\
\text { North Carolina } \\
\text { Oklahoma, Virginia } \\
\text { Wyoming }\end{array}$ & Bank holidays \\
\hline 4 March & $\begin{array}{l}\text { Colorado, Delaware } \\
\text { District of Columbia } \\
\text { Florida, Georgia } \\
\text { Kansas, Maine } \\
\text { Massachusetts } \\
\text { Minnesota } \\
\text { Missouri } \\
\text { Montana, Nebraska } \\
\text { New Hampshire } \\
\text { New Jersey } \\
\text { New York } \\
\text { North Dakota } \\
\text { South Dakota } \\
\text { Vermont }\end{array}$ & $\begin{array}{l}\text { Virtually all remaining banks closed by } \\
\text { governor's proclamations at the request } \\
\text { of Treasury officials. New York holds } \\
\text { out for a few hours; They cannot get } \\
\text { hold of governor of Illinois }\end{array}$ \\
\hline 6 March & United States & Bank Holiday \\
\hline
\end{tabular}




\begin{tabular}{|c|c|}
\hline \multicolumn{2}{|r|}{ Table 3} \\
\hline \multicolumn{2}{|r|}{ State Bank Restrictions, Sunday, March 5, 1933} \\
\hline State & Description of Restrictions \\
\hline Alabama & Closed until further notice \\
\hline Arizona & Closed until March 13 \\
\hline Arkansas & Closed until March 7 \\
\hline California & Almost all closed until March 9 \\
\hline Colorado & Closed until March 8 \\
\hline Connecticut & Closed until March 7 \\
\hline Delaware & Closed indefinitely \\
\hline District of Columbia & Three banks limited to $5 \%$; nine savings banks invoke sixty days' notice \\
\hline Florida & Withdrawals restricted to $5 \%$ plus $\$ 10$ until March 8 \\
\hline Georgia & Mostly closed until March 7, closing optional \\
\hline Idaho & Some closed until March 18 , closing optional \\
\hline Illinois & $\begin{array}{l}\text { Closed until March } 8 \text {, then to be opened on } 5 \% \text { restriction basis for } \\
\text { seven days }\end{array}$ \\
\hline Indiana & About half restricted to $5 \%$ indefinitely \\
\hline lowa & Closed "temporarily" \\
\hline Kansas & Restricted to $5 \%$ withdrawals indefinitely \\
\hline Kentucky & Mostly restricted to $5 \%$ withdrawals until March 11 \\
\hline Louisiana & Closing mandatory until March 7 \\
\hline Maine & Closed until March 7 \\
\hline Maryland & Closed until March 6 \\
\hline Massachusetts & Closed until March 7 \\
\hline Michigan & $\begin{array}{l}\text { Mostly closed, others restricted to } 5 \% \text { indefinitely; Upper peninsula } \\
\text { banks open }\end{array}$ \\
\hline Minnesota & Closed "temporarily" \\
\hline Mississippi & Restricted to $5 \%$ indefinitely \\
\hline Missouri & Closed until March 7 \\
\hline
\end{tabular}




\begin{tabular}{|c|c|}
\hline Montana & Closed until further notice \\
\hline Nebraska & Closed until March 8 \\
\hline Nevada & Closed until March 8, also schools \\
\hline New Hampshire & Closed subject to further proclamation \\
\hline New Jersey & Closed until March 7 \\
\hline New Mexico & Mostly closed until March 8 \\
\hline New York & Closed until March 7 \\
\hline North Carolina & Some banks restricted to $5 \%$ withdrawals \\
\hline North Dakota & Closed temporarily \\
\hline Ohio & Mostly restricted to $5 \%$ withdrawals indefinitely \\
\hline Oklahoma & All closed until March 8 \\
\hline Oregon & All closed until March 7 \\
\hline Pennsylvania & Mostly closed until March 7, Pittsburgh banks open \\
\hline Rhode Island & Closed yesterday \\
\hline South Carolina & Some closed, some restricted, all on own initiative \\
\hline South Dakota & Closed indefinitely \\
\hline Tennessee & A few closed, others restricted, until March 9 \\
\hline Texas & Mostly closed, others restricted to withdrawals of $\$ 15$ daily until March 8 \\
\hline Utah & Mostly closed until March 8 \\
\hline Vermont & Closed until March 7 \\
\hline Virginia & All closed until March 8 \\
\hline Washington & Some closed until March 7 \\
\hline West Virginia & Restricted to $5 \%$ monthly withdrawals indefinitely \\
\hline Wisconsin & Closed until March 17 \\
\hline Wyoming & Withdrawals restricted to $5 \%$ indefinitely \\
\hline
\end{tabular}




\begin{tabular}{|c|c|c|c|c|c|}
\hline \multicolumn{6}{|c|}{ Table 4} \\
\hline \multicolumn{6}{|c|}{ Effects of Adjusting the Monetary Aggregates for Restricted Deposits } \\
\hline \multicolumn{6}{|c|}{ Sample Period $=1921.051940 .12$} \\
\hline Variable & (1) & (2) & (3) & (4) & (5) \\
\hline $\begin{array}{l}\text { Dependent } \\
\text { Variable }\end{array}$ & IP & IP & IP & MRIP & DSS \\
\hline Definition of Money & M1 & M1a & M1a & M1a & M1a \\
\hline Dependent Variable(-1) & $\begin{array}{c}.552 \\
(8.81) \\
\end{array}$ & $\begin{array}{c}.550 \\
(8.98) \\
\end{array}$ & $\begin{array}{c}.543 \\
(8.46)\end{array}$ & $\begin{array}{l}-.351 \\
(5.36)\end{array}$ & $\begin{array}{l}-.365 \\
(5.53) \\
\end{array}$ \\
\hline $\begin{array}{l}\text { Dependent } \\
\text { Variable(-2) }\end{array}$ & $\begin{array}{l}-.3 .43 \\
(5.47) \\
\end{array}$ & $\begin{array}{c}-.369 \\
(6.07) \\
\end{array}$ & $\begin{array}{l}-.358 \\
(5.80) \\
\end{array}$ & $\begin{array}{l}-.084 \\
(1.28) \\
\end{array}$ & $\begin{array}{l}-.162 \\
(2.43) \\
\end{array}$ \\
\hline Money & $\begin{array}{c}.416 \\
(2.65)\end{array}$ & $\begin{array}{c}.380 \\
(6.16)\end{array}$ & $\begin{array}{c}.294 \\
(2.50)\end{array}$ & $\begin{array}{c}.414 \\
(1.09)\end{array}$ & $\begin{array}{c}.363 \\
(4.05)\end{array}$ \\
\hline Money(-1) & $\begin{array}{c}.298 \\
(1.93) \\
\end{array}$ & $\begin{array}{c}.217 \\
(3.23) \\
\end{array}$ & $\begin{array}{r}.359 \\
(2.68) \\
\end{array}$ & $\begin{array}{r}.393 \\
(.919) \\
\end{array}$ & $\begin{array}{r}.418 \\
(4.10) \\
\end{array}$ \\
\hline Money(-2) & $\begin{array}{c}.035 \\
(.229) \\
\end{array}$ & $\begin{array}{c}.154 \\
(2.25) \\
\end{array}$ & $\begin{array}{r}.126 \\
(1.83) \\
\end{array}$ & $\begin{array}{c}.747 \\
(3.50) \\
\end{array}$ & $\begin{array}{c}.132 \\
(2.39)\end{array}$ \\
\hline Money(-3) & $\begin{array}{c}.058 \\
(.368) \\
\end{array}$ & $\begin{array}{c}.062 \\
(.963) \\
\end{array}$ & $\begin{array}{c}.054 \\
(.860) \\
\end{array}$ & $\begin{array}{c}.711 \\
(3.50) \\
\end{array}$ & $\begin{array}{c}.106 \\
(2.28) \\
\end{array}$ \\
\hline DBANKS & & & $\begin{array}{l}-.300 \\
(.283) \\
\end{array}$ & $\begin{array}{c}.483 \\
(.141) \\
\end{array}$ & $\begin{array}{r}.544 \\
(.677) \\
\end{array}$ \\
\hline DBANKS(-1) & & & $\begin{array}{l}1.608 \\
(1.24)\end{array}$ & $\begin{array}{l}-2.80 \\
(.667)\end{array}$ & $\begin{array}{c}1.66 \\
(1.71)\end{array}$ \\
\hline DFAILS & & & $\begin{array}{l}-48.00 \\
(2.57) \\
\end{array}$ & $\begin{array}{c}1.34 \\
(.022) \\
\end{array}$ & $\begin{array}{l}-9.09 \\
(.658) \\
\end{array}$ \\
\hline DFAILS(-1) & & & $\begin{array}{c}11.4 \\
(.599) \\
\end{array}$ & $\begin{array}{l}-5.46 \\
(.092) \\
\end{array}$ & $\begin{array}{l}-8.75 \\
(.634) \\
\end{array}$ \\
\hline Adjusted R2 & 299 & .372 & .390 & .128 & .271 \\
\hline
\end{tabular}




\begin{tabular}{|c|c|c|c|c|c|}
\hline \multicolumn{6}{|c|}{ Table 5} \\
\hline \multicolumn{6}{|c|}{ Adding a quality variable to the explanatory equation } \\
\hline \multicolumn{6}{|c|}{ Sample Period $=1921.05-1940.12$} \\
\hline Variable & (1) & (2) & (3) & (4) & (5) \\
\hline & IP & IP & IP & MRIP & DSS \\
\hline Dependent Variable(-1) & $\begin{array}{c}.552 \\
(8.805) \\
\end{array}$ & $\begin{array}{c}.559 \\
(8.96) \\
\end{array}$ & $\begin{array}{c}.572 \\
(8.89) \\
\end{array}$ & $\begin{array}{r}-.307 \\
4.59 \\
\end{array}$ & $\begin{array}{r}-.357 \\
(5.36) \\
\end{array}$ \\
\hline $\begin{array}{l}\text { Dependent } \\
\text { Variable(-2) }\end{array}$ & $\begin{array}{r}-.343 \\
(5.47) \\
\end{array}$ & $\begin{array}{r}-.356 \\
(5.73) \\
\end{array}$ & $\begin{array}{r}-.348 \\
(5.71) \\
\end{array}$ & $\begin{array}{c}-.039 \\
.579 \\
\end{array}$ & $\begin{array}{l}-.113 \\
(1.76) \\
\end{array}$ \\
\hline M1 & $\begin{array}{r}.416 \\
(2.65) \\
\end{array}$ & $\begin{array}{c}.048 \\
(.248) \\
\end{array}$ & $\begin{array}{c}.053 \\
(.281) \\
\end{array}$ & $\begin{array}{r}-.768 \\
(1.23) \\
\end{array}$ & $\begin{array}{c}.091 \\
(.645) \\
\end{array}$ \\
\hline M1(-1) & $\begin{array}{c}.298 \\
(1.93) \\
\end{array}$ & $\begin{array}{c}.311 \\
(1.54) \\
\end{array}$ & $\begin{array}{c}.472 \\
(2.35) \\
\end{array}$ & $\begin{array}{r}.133 \\
(.198) \\
\end{array}$ & $\begin{array}{r}.524 \\
(3.44) \\
\end{array}$ \\
\hline M1(-2) & $\begin{array}{c}.035 \\
(.229)\end{array}$ & $\begin{array}{c}.067 \\
(.439)\end{array}$ & $\begin{array}{c}.165 \\
(1.11)\end{array}$ & $\begin{array}{c}1.04 \\
(2.14)\end{array}$ & $\begin{array}{c}.228 \\
(1.99)\end{array}$ \\
\hline $\mathrm{M} 1(-3)$ & $\begin{array}{c}.057 \\
(.368) \\
\end{array}$ & $\begin{array}{c}.088 \\
(.567) \\
\end{array}$ & $\begin{array}{l}.091 \\
(.608)\end{array}$ & $\begin{array}{c}.452 \\
(.897) \\
\end{array}$ & $\begin{array}{l}.110 \\
(.965) \\
\end{array}$ \\
\hline QUALITY & & $\begin{array}{c}1.30 \\
(2.94) \\
\end{array}$ & $\begin{array}{c}.837 \\
(1.92) \\
\end{array}$ & $\begin{array}{c}2.10 \\
(1.44) \\
\end{array}$ & $\begin{array}{l}(.872) \\
(2.62)\end{array}$ \\
\hline QUALITY(-1) & & $\begin{array}{l}-.035 \\
(.075) \\
\end{array}$ & $\begin{array}{r}-.626 \\
(1.20) \\
\end{array}$ & $\begin{array}{c}.826 \\
(.474) \\
\end{array}$ & $\begin{array}{r}-.465 \\
(1.13) \\
\end{array}$ \\
\hline DBANKS & & & $\begin{array}{l}-2.83 \\
(4.00) \\
\end{array}$ & $\begin{array}{r}-.309 \\
(.131) \\
\end{array}$ & $\begin{array}{r}-2.46 \\
(4.47) \\
\end{array}$ \\
\hline DBANKS(-1) & & & $\begin{array}{c}-.850 \\
(1.19) \\
\end{array}$ & $\begin{array}{l}-2.27 \\
(.971) \\
\end{array}$ & $\begin{array}{l}-1.10 \\
(1.96) \\
\end{array}$ \\
\hline DFAILS & & & $\begin{array}{l}-45.7 \\
(2.42) \\
\end{array}$ & $\begin{array}{l}-.129 \\
(.210) \\
\end{array}$ & $\begin{array}{l}-8.41 \\
(.603) \\
\end{array}$ \\
\hline DFAILS $(-1)$ & & & $\begin{array}{c}8.38 \\
(.439) \\
\end{array}$ & $\begin{array}{l}-.180 \\
(.296) \\
\end{array}$ & $\begin{array}{l}-.156 \\
(1.12) \\
\end{array}$ \\
\hline Adjusted R2 & .299 & .321 & .382 & .077 & .257 \\
\hline
\end{tabular}




\begin{tabular}{|c|c|c|c|c|c|}
\hline \multicolumn{6}{|c|}{ Table 6} \\
\hline \multicolumn{6}{|c|}{ Adding the ratio of gold to money to the explanatory equation } \\
\hline \multicolumn{6}{|c|}{ Sample Period $=1921.05-1933.12$} \\
\hline Variable & (1) & (2) & (3) & (4) & (5) \\
\hline Dependent Variable & IP & IP & IP & MRIP & DSS \\
\hline Dependent Variable(-1) & $\begin{array}{c}.487 \\
(6.16)\end{array}$ & $\begin{array}{c}.392 \\
(5.05)\end{array}$ & $\begin{array}{c}.505 \\
(6.49)\end{array}$ & $\begin{array}{l}-.252 \\
(3.01)\end{array}$ & $\begin{array}{l}-.413 \\
(4.97)\end{array}$ \\
\hline $\begin{array}{l}\text { Dependent } \\
\text { Variable }(-2)\end{array}$ & $\begin{array}{l}-.328 \\
(4.12) \\
\end{array}$ & $\begin{array}{l}-.406 \\
(5.17)\end{array}$ & $\begin{array}{l}-.376 \\
(4.78)\end{array}$ & $\begin{array}{c}.058 \\
(.708)\end{array}$ & $\begin{array}{l}-.132 \\
(1.60)\end{array}$ \\
\hline M1 & $\begin{array}{c}.397 \\
(1.82)\end{array}$ & $\begin{array}{c}.282 \\
(1.33)\end{array}$ & $\begin{array}{l}-.025 \\
(.124)\end{array}$ & $\begin{array}{l}-.575 \\
(.921)\end{array}$ & $\begin{array}{r}.096 \\
(.606)\end{array}$ \\
\hline M1(-1) & $\begin{array}{c}.245 \\
(1.11)\end{array}$ & $\begin{array}{c}.309 \\
(1.43)\end{array}$ & $\begin{array}{c}.377 \\
(1.92)\end{array}$ & $\begin{array}{l}-.303 \\
(.492)\end{array}$ & $\begin{array}{l}.109 \\
(.678)\end{array}$ \\
\hline M1(-2) & $\begin{array}{c}-.373 \\
(1.71)\end{array}$ & $\begin{array}{l}-.156 \\
(.727)\end{array}$ & $\begin{array}{c}.088 \\
(.433)\end{array}$ & $\begin{array}{c}.982 \\
(1.55)\end{array}$ & $\begin{array}{r}.506 \\
(3.11)\end{array}$ \\
\hline $\mathbf{M} 1(-3)$ & $\begin{array}{r}.006 \\
(.026) \\
\end{array}$ & $\begin{array}{c}.162 \\
(.761) \\
\end{array}$ & $\begin{array}{r}.187 \\
(.971) \\
\end{array}$ & $\begin{array}{c}.711 \\
(1.18) \\
\end{array}$ & $\begin{array}{r}.483 \\
(3.16) \\
\end{array}$ \\
\hline GOLD-M1 & & $\begin{array}{l}-.065 \\
(2.87)\end{array}$ & $\begin{array}{l}-.149 \\
(5.40)\end{array}$ & $\begin{array}{r}-.119 \\
(1.37)\end{array}$ & $\begin{array}{l}-.047 \\
(2.12)\end{array}$ \\
\hline GOLD-M1(-1) & & $\begin{array}{l}-.072 \\
(3.03)\end{array}$ & $\begin{array}{c}.089 \\
(2.44)\end{array}$ & $\begin{array}{c}.083 \\
(.754)\end{array}$ & $\begin{array}{r}-.051 \\
(1.83)\end{array}$ \\
\hline GOLD-M1(-2) & & $\begin{array}{r}-.030 \\
(1.23)\end{array}$ & $\begin{array}{l}-.020 \\
(.513)\end{array}$ & $\begin{array}{l}-.021 \\
(.187)\end{array}$ & $\begin{array}{l}.0004 \\
(.015)\end{array}$ \\
\hline GOLD-M1(-3) & & $\begin{array}{l}-.041 \\
(1.73)\end{array}$ & $\begin{array}{l}-.042 \\
(1.78)\end{array}$ & $\begin{array}{l}-.186 \\
(2.49)\end{array}$ & $\begin{array}{r}-.040 \\
(1.99)\end{array}$ \\
\hline DBANKS & & & $\begin{array}{l}-5.93 \\
(5.62)\end{array}$ & $\begin{array}{l}-5.21 \\
(1.60)\end{array}$ & $\begin{array}{r}-2.57 \\
(3.12)\end{array}$ \\
\hline DBANKS(-1) & & & $\begin{array}{l}-1.96 \\
(1.69)\end{array}$ & $\begin{array}{l}-5.65 \\
(1.68)\end{array}$ & $\begin{array}{l}-2.08 \\
(2.41)\end{array}$ \\
\hline DFAILS & & & $\begin{array}{l}-34.4 \\
(1.65)\end{array}$ & $\begin{array}{l}-34.8 \\
(.534)\end{array}$ & $\begin{array}{c}3.82 \\
(.232)\end{array}$ \\
\hline DFAILS(-1) & & & $\begin{array}{c}2.79 \\
(.134)\end{array}$ & $\begin{array}{l}-55.0 \\
(.859)\end{array}$ & $\begin{array}{l}-1.49 \\
(.092)\end{array}$ \\
\hline Adjusted R2 & .246 & .336 & .468 & .068 & .331 \\
\hline
\end{tabular}


Appendix

Divisia Monetary Aggregates During the Great Depression

The Divisia monetary aggregate, and related indexes, seem a natural way to allow for quality effects during the Great Depression because they incorporate price information that might measure changes in the monetary services produced by a given quantity of money. Since they make use of standard formulas, moreover, there is no need to estimate elasticities of demand or substitution in order to use them. A recent paper by Barnett, Fisher, and serletis (1992) describes these indexes and makes a strong case for them. Experiments with these indexes, however, proved disappointing for the quality interpretation. I am unpersuaded, however, that the failure of these indexes to support the quality interpretation should be considered decisive.

The basic idea behind indexes of this sort is that the monetary services produced by a dollar of deposits or other liquid assets can be measured by the user cost of holding a dollar. Suppose the rate of return on a corporate bond that produces no monetary services is 8 percent, and that a bank deposit account pays 5 percent. Then the opportunity cost of the nonpecuniary services produced by a dollar of deposits is 3 percent per year; for currency the opportunity cost would be the full 8 percent. ${ }^{14}$

Different indexes make use of the user cost in slightly different ways. The simplest idea is to view the user cost as an

${ }^{14}$ We can ignore the distinction between real and nominal returns here, because subtracting the inflation rate from both the corporate bond rate and the deposit account would leave the user cost unchanged. 
annual return and then to divide by the return on bonds to get the present value of the monetary services generated by holding a dollar of a particular asset. Thus, for deposits, 3 percent divided by 8 percent gives $\$ .38$ in monetary services per dollar of deposits. We can then construct a weighted monetary aggregate by weighting total currency by one and total deposits by .38. This is the index recently proposed by Rotemberg, Driscoll, and Poterba (1991). The formula would be

(A1) $\mathrm{RDP} \mathrm{M} 1=\mathrm{C}+\{(\mathrm{rb}-\mathrm{rd}) / \mathrm{rb}\} * \mathrm{D}$

where $C$ is currency, $D$ is deposits, $r b$ is the rate of return on bonds, and $\mathrm{rd}$ is the rate of return on deposits. The formula could be extended by adding additional liquid assets weighted by their discounted user costs.

The Divisia index and the Fisher Ideal index make use of the user cost in more complicated ways. The Divisia Index is easier to understood in rate of change form.

(A2) $\log ($ Divisia Mt) $-\log ($ Divisia Mt-1) $=$

$(1 / 2)(S c t+S c t-1)(\log c t-\log c t-1)+$

$(1 / 2)(S d t+S d t-1)(\log D t-\log D t-1)$

where $S c=r b * c /[r b * c+(r b-r d) * D]$, is the share of the monetary services of currency in total monetary services. Thus, the percentage change in the Divisia index in each period is the sum of the percentage changes in each monetary asset weighted by the average shares of monetary services.

Fisher's Ideal index, in rate of change form, is given by

(A3) $\log ($ Fisher's Mt) - $\log ($ Fisher's Mt-1) $=$

$(1 / 2)\{\log (S c t-1[C t / C t-1]+S d t-1[D t / D t-1])-$

$\log (\operatorname{Sct}[\mathrm{Ct}-1 / \mathrm{Ct}]+\operatorname{Sdt}[\mathrm{Dt}-1 / \mathrm{Dt}])\}$

There does not appear to be an equally intuitive 
interpretation of Fisher's index, but as you can see it also makes use of the share of monetary services produced by a given asset for weighting changes in that asset. I computed the value of each of these indexes using the high-grade corporate bond rate (Friedman and Schwartz, 1982, 124) for the benchmark rate, and the interest rates on deposits from Cagan (1965, 318).

The results, however, were uniformly counterintuitive.

Figures $A 1, A 2$, and $A 3$ compare percentage changes in the standard estimates of $M 1$ with the corresponding percentage change in the Rotemberg-Driscoll-Poterba M1, the Divisia M1, and the Fisher M1, respectively. The Rotemberg-Driscoll-Poterba M1 index shows decidedly less contraction than the standard M1. Indeed, it doesn't show any substantial declines before 1931. The other two indexes track the standard M1 fairly closely, although there is a small difference in 1931 and 1932 when both the Divisia index and the Fisher index fall slightly less than the standard M1. The results for M2 were similar.

There are several possible interpretations of these results (barring the simplest one that $I$ have gotten a sign wrong somewhere). (1) There is some problem with the data used to compute the indexes. But I know of no obvious bias in the data, at least before 1933. After 1933 interest payments were prohibited on deposit accounts, and there may have been some attempt to evade this restriction, although one would not think this problem was important given the depressed conditions of the 1930s. (2) The user-cost formulas are telling us that my quality-argument is wrong, and that the monetary contraction argument as a whole is weaker than previously thought, because the true monetary contraction was less severe than standard monetary estimates 
suggest in the crucial years of the Depression. But the fact that the difference is not only small but goes in the wrong direction suggests that the Divisia indexes are not adjusting for quality as I have been defining it. (3) The user-cost formulas need to be modified in some way to handle a banking crisis and Depression. Risk neutrality, which may be an innocuous assumption in ordinary circumstances, may need to be modified for the Depression. Hopefully, some way can be found for adapting the Divisia aggregates to the Depression that will not undermine their characteristic simplicity and objectivity.

46 


\section{APPENDIX REFERENCES}

Barnett, william A., Douglas Fisher, and Apostolos Serletis. 1992. "Consumer Theory and the Demand for Money." Journal of Economic Literature, 30 (December): 2086-2119.

Cagan, Phillip. 1965. Determinants and Effects of Changes in the Stock of Money, 1875-1960. New York: Columbia U. Press, for the NBER.

Friedman, Milton and Anna J. Schwartz. 1982. Monetary Trends in the United states and the United Kingdom: Their Relation to Income, Prices, and Interest Rates, 1867-1875. Chicago: University of Chicago Press.

Rotemberg, Julio J., John C. Driscoll, and James M. Poterba. 1991. "Money, Output, and Prices: Evidence From A New Monetary Aggregate." NBER Working Paper No. 3824. 

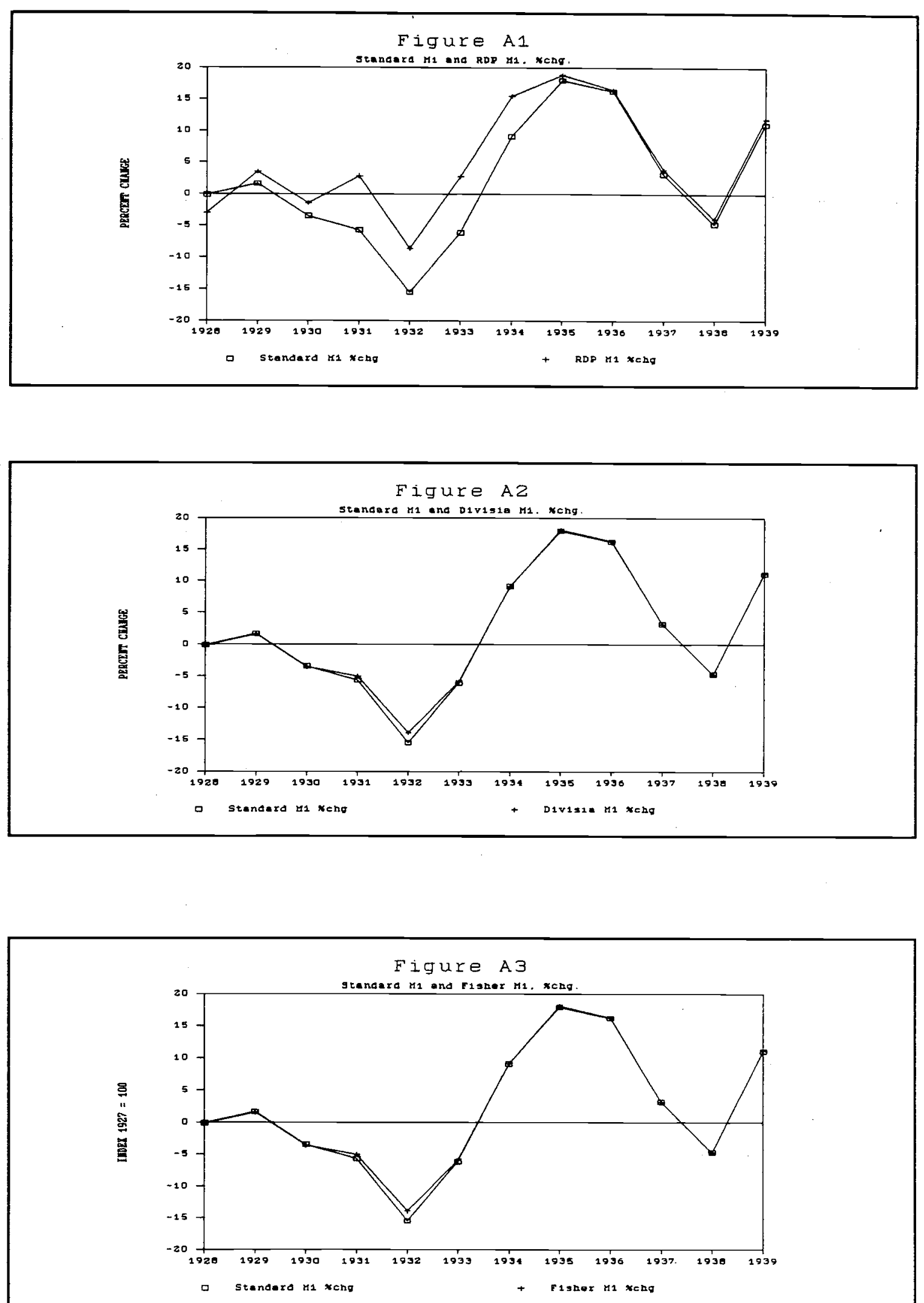